\title{
Leaching of salt-affected soil amended by leonardite
}

\author{
Jie Wang ${ }^{a, b, c}$, Guodong Yuan ${ }^{a, d}$, Jian $L^{a, b, c}$ and Jun Wu \\ aCAS Key Laboratory of Coastal Environmental Processes and Ecological Remediation, Yantai Institute of \\ Coastal Zone Research (YIC), Chinese Academy of Sciences (CAS), Yantai, Shandong, P. R. China; ${ }^{\text {bShandong }}$ \\ Key Laboratory of Coastal Environmental Processes, YICCAS, Yantai, Shandong, P. R. China; 'University of

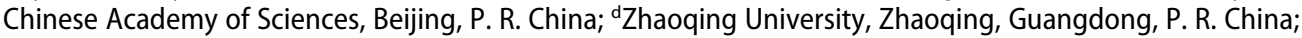 \\ eSchool of Resources and Environmental Engineering, Ludong University, Yantai, Shandong, P. R. China
}

\begin{abstract}
Salt-affected soils are widely distributed in arable croplands worldwide with potential productivity so that it is important to develop and utilize these soils. This study investigated the effects of leonardite at the application dosage of 0 (CK), 1\% (T1), 3\% (T2), and 5\% (T3) on amending salt-affected soils under intermittent leaching. Results showed that leaching effectively reduced the electrical conductivity (EC) in soil at CK/T1/T2/T3 with 67.4\%/70.9\%/75.7\%/ $75.6 \%$ of salt discharged. As the dominant cation in leachates, $\mathrm{Na}^{+}$ removed accounted for $75.1 \%$ (CK), 79.7\% (T1), $72.6 \%$ (T2), and $71.5 \%$ (T3) of the total cation in soil. Sodium adsorption ratio of soil column for CK/T1/T2/T3 treatment decreased by $61.1 \% / 68.1 \%$ / $50.0 \% / 44.9 \%$. Organic matters in the soil reached 9.74/17.20/31.41/ $42.88 \mathrm{~g} / \mathrm{kg}$ for CK/T1/T2/T3 treatment at the end of the experiment, indicating a fertile prospect for reclamation of the salt-affected soils. Soil $\mathrm{pH}$ increased with leonardite dosage after leaching in a similar pattern as the decline of EC. The results would provide practical assistance for amending salt-affected soil in the Yellow River Delta.
\end{abstract}

\section{ARTICLE HISTORY}

Received 13 November 2019 Accepted 29 February 2020

\section{KEYWORDS}

Salt-affected soil; leonardite; amelioration; leaching;

Yellow River Delta

\section{Introduction}

Salt-affected soils have been widely distributed in more than 100 countries, especially in arid and semi-arid regions of the world (Saifullah et al., 2018). Approximately 36 million $\mathrm{hm}^{2}$ land is evaluated as saline soil in China (Liu et al., 2015). The cultivated land per capita in China was only 0.09 ha in 2008, much lower than the world average land of 0.236 ha (Huang et al., 2011). Therefore, it is urgent to find more lands suitable for agriculture in China since China possesses the largest population in the world. The rehabilitation and utilization of saline soil have become a very important practice to alleviate the contradiction between the shortage of land resources and increased population in China and other countries with a large quantity of salt-affected lands.

One obstacle of culturing on salt-affected soil is the excessive salts accumulated in the soil profile occupied by root systems (Diacono \& Montemurro, 2015). In addition, saltaffected soil is usually deteriorated in soil structure and inefficient in nutrient availability, land use rate and productivity of crops. Thus, many amelioration methods including 
drainage facilities, chemical amendments, and phytoremediation have been applied for amending salt-affected soils (Ghafoor et al., 2012; Mau \& Porporato, 2016). Leaching is a typical method for removing soluble salts from the topsoil by water and plays an important role in reclaiming salt-affected soils (Shaygan et al., 2018).

Low organic matter content is another factor restricting the productivity of salt-affected soil. Salt content and poor soil structure inhibit plant growth, which causes less accumulation of organic carbon in plant residues and accelerates organic matters to be leached out with precipitation (Lakhdar et al., 2009; Raychev et al., 2001). It is important to retain organic matter in soil, especially salt-affected soils (Srivastava et al., 2016). Leonardite, a kind of oxidized shallow coal with low combustion value, contains a lot of humic substances that provide huge adsorption and buffer ability to promote seed germination and root growth (Barone et al., 2019; Dobrzanski \& Anyszka, 2008). In addition, the market price of leonardite in China is about $30 \mathrm{USD} / \mathrm{t}$ at present, far lower than that of the current emerging soil improvement materials such as biochar whose average price is $2650 \mathrm{USD} / \mathrm{t}$ globally (Ahmed et al., 2016). The effects of soil improvement will last for years after application and only a fraction of ameliorator is initially degraded to make it available for plants and soil microorganisms (Gao et al., 2012). The grain yield of the study area is only one-third to half of that in the normal soil due to the excessive salt retained in the topsoil. Therefore, the cost-efficient leonardite will become a potentially useful material for amelioration of salt-affected soil.

The study area, the Yellow River Delta, has $78 \%$ of the precipitation in summer to readily leach soluble salts and dissolved organic materials (DOM) from soils due to large amount of rainfall. Therefore, the main aim of this study is to determine the influence of leonardite on salt-affected soil under the simulation of summer rainfall. The final goal of this study is to understand the leaching behaviors of cations and organic matters so as to predict the consequences of the organic ameliorator for amending the salt-affected soils.

\section{Materials and methods}

\section{Soil sampling and leonardite}

The study area is located in the Yellow River Delta of China (N37 $55^{\prime} 14.17^{\prime \prime}, \mathrm{E} 118^{\circ} 48^{\prime}$ $\left.59.14^{\prime \prime}\right)$. The mean annual precipitation in the study area is only $564 \mathrm{~mm}$ with $78 \%$ of rainfall occurring from June to September (Mao et al., 2016). The top tilled soils with $20 \mathrm{~cm}$ depth were obtained from the field before winter wheat sowing (in October 2017). After air drying, the soil samples were crushed to pass through the $1 \mathrm{~mm}$ sieve. The soil used in this study was silty clay according to American soil texture standard to represent the soil texture of the surface horizon. The physicochemical properties of the soil are present in Table 1. Salt content of the salt-affected soil was measured as $2.6 \%$ (Bao, 2005) and the soil organic matter was $11.01 \mathrm{~g} / \mathrm{kg}$.

Leonardite used in this study was purchased from Shandong Innovation Company (Shandong, China). Leonardite was rich in organic matters with $44.21 \%$ of carbon and $23.7 \%$ of ash (Table 1). The content of functional groups including carboxyl (-COOH) and phenolic $(-\mathrm{OH})$ was 2.01 and $1.75 \mathrm{~mol} / \mathrm{kg}$, respectively. These functional groups were involved in cation exchange capacity, absorption, and complexation (Saifullah et al., 2018) and further affected soil properties and physiological properties of plants (Abiala et al., 2018; 
Table 1. Basic characters of soil and leonardite.

\begin{tabular}{|c|c|c|c|c|c|c|c|c|}
\hline \multirow[b]{2}{*}{ Sample } & \multirow[b]{2}{*}{$\mathrm{pH}$} & \multirow[b]{2}{*}{$\mathrm{EC}(\mathrm{dS} / \mathrm{m})$} & \multirow[b]{2}{*}{$\begin{array}{c}\mathrm{CEC} \\
\mathrm{cmol} / \mathrm{kg}\end{array}$} & \multirow[b]{2}{*}{ Salinity } & \multirow[b]{2}{*}{$\begin{array}{c}\text { Organic matters } \\
\mathrm{g} / \mathrm{kg}\end{array}$} & Sand & Silt & Clay \\
\hline & & & & & & \multicolumn{3}{|c|}{$-(\%)-$} \\
\hline \multirow[t]{2}{*}{ Soil } & 7.56 & 0.89 & 16.22 & Slightly & 11.01 & 10.55 & 39.76 & 49.70 \\
\hline & & & & $-\mathrm{COOH}$ & phenol-OH & Ash & C & $\mathrm{N}$ \\
\hline Material & $\mathrm{pH}$ & $\mathrm{EC}(\mathrm{dS} / \mathrm{m})$ & CEC cmol/kg & \multicolumn{2}{|c|}{$-(\mathrm{mol} / \mathrm{kg})-$} & \multicolumn{3}{|c|}{$-(\%)-$} \\
\hline Leonardite & 3.84 & 7.84 & 163.72 & 2.01 & 1.75 & 23.70 & 44.21 & 0.91 \\
\hline
\end{tabular}

Olaetxea et al., 2018). The $\mathrm{pH}$ and electrical conductivity (EC) of leonardite in water extraction were measured at 1:5 solid-liquid ratio and shown in Table 1.

\section{Leaching experiment}

Leaching columns used in this study were made of polypropylene with an internal diameter of $5 \mathrm{~cm}$. The cylinders were filled with clean gauze at the bottom to prevent soil loss with leachate. A hole was drilled at the end caps while drain tubes were attached to the bottom of each column by a rubber. Every $5 \mathrm{~cm}$ soil was compacted to finally form a $20 \mathrm{~cm}$ soil column. All columns were packed to the bulk density of $1.31 \mathrm{~g} / \mathrm{cm}^{3}$ according to the field measurement. Before columns filling, a predetermined amount of leonardite was mixed fully with the dried soil to obtain the final leonardite content of 0/10/30/50 g/kg for CK (control)/T1/T2/T3. Each treatment had three replicates. Deionized water was simulated as the rainfall in summer with a volume of $50 \mathrm{ml}$ that was determined according to the rainfall amount of heavy rain. Each leaching was dripped drop by drop and accomplished within $24 \mathrm{~h}$ for every 3 days. The experiment was completed after seven leaching events. Leachate from each column was collected in a $100 \mathrm{ml}$ polyethylene bottle and weighed as the weight difference of empty bottle and bottle containing leachate. The leachate volume could be calculated using leachate weight divided by the density of $1.0 \mathrm{~g} / \mathrm{cm}^{3}$. EC, $\mathrm{pH}$, soluble cations $\left(\mathrm{Na}^{+}, \mathrm{Ca}^{2+}, \mathrm{Mg}^{2+}\right.$, and $\left.\mathrm{K}^{+}\right)$and total organic carbon (TOC) of the leachate were determined. The ratio of absorbance of DOM solution at 250 and $365 \mathrm{~nm}\left(\mathrm{E}_{2} / \mathrm{E}_{3}\right)$ as well as 465 and $665 \mathrm{~nm}\left(\mathrm{E}_{4} / \mathrm{E}_{6}\right)$ was measured.

\section{Soil chemical analyses}

The initial soil solution before leaching was obtained. Soil or soil-leonardite mixtures (weight of $8 \mathrm{~g}$ ) with the soil-liquid ratio of 1:5 were distributed in $50 \mathrm{ml}$ centrifugal tubes before leaching for extraction. Afterwards the tubes were put on the shaking table at the rate of $300 \mathrm{rpm} / \mathrm{min}$ for 7 days. Soil extract was filtered by $0.45 \mu \mathrm{m}$ membrane. EC, $\mathrm{pH}$, soluble cations $\left(\mathrm{Na}^{+}, \mathrm{Ca}^{2+}, \mathrm{Mg}^{2+}\right.$, and $\left.\mathrm{K}^{+}\right)$at a 1:5 solid-liquid ratio were measured and soil organic matter (SOM) was also measured according to the method documented in Soil Agricultural Chemistry Analysis (Bao, 2005). In order to evaluate the differences of 
soil property before and after leaching, columns were dismantled after the leaching process was finished and the soil samples were analyzed after air-drying and passing $1 \mathrm{~mm}$ sieve.

Soluble salt content of the soil extract solution was determined by the residual drying method. CEC (cation exchange capacity) was determined using a sodium acetate - flame photometry method. The organic matter in the soil was by potassium dichromate heating method. The total mass of $\mathrm{Na}^{+}, \mathrm{Ca}^{2+}, \mathrm{Mg}^{2+}$, and $\mathrm{K}^{+}$in digestion extract was determined according to the $\mathrm{HNO}_{3}-\mathrm{HClO}_{4}$ - $\mathrm{HF}$ method. All the above-mentioned methods referred to Bao (2005). EC was measured by Rex DDS-11A conductivity meters (Shanghai INESA Scientific Instrument Co., Ltd, China). Soluble cations $\left(\mathrm{Na}^{+}, \mathrm{Ca}^{2+}, \mathrm{Mg}^{2+}\right.$, and $\left.\mathrm{K}^{+}\right)$were analyzed by Ion Chromatography, Dionex ICS3000 (Dionex Corporation, USA). The contents of $-\mathrm{COOH}$ and phenol $-\mathrm{OH}$ in biochar and peat were determined through titration method provided by the International Humic Substances Society (http://humicsubstances.org/). The ratios of $\mathrm{E}_{2} / \mathrm{E}_{3}$ (Peuravuori \& Pihlaja, 1997) and $\mathrm{E}_{4} / \mathrm{E}_{6}$ (Chen et al., 1977) were obtained by the Genesys $10 \mathrm{~S}$ UV-Vis Spectrophotometer (Thermo Fisher Scientific, USA) in a 1 -cm quartz cuvette.

\section{Statistical analyses}

Origin 8.1, Excel 2003 and SPSS 9.0 were employed in data analysis. One-way ANOVA was performed to determine the difference of means for the soil analysis results, followed by Duncan's multiple comparison test $(P<0.05)$.

Sodium adsorption ratio $(\mathrm{SAR})\left[(\mathrm{mmol} / \mathrm{l})^{\wedge} 0.5\right]$ was calculated by the following equation (Miller et al., 2017):

$$
\mathrm{SAR}=\frac{\left[\mathrm{Na}^{+}\right]}{\sqrt{\left[\mathrm{Ca}^{2+}\right]+\left[\mathrm{Mg}^{2+}\right]}}
$$

where $\left[\mathrm{Na}^{+}\right],\left[\mathrm{Ca}^{2+}\right]$ and $\left[\mathrm{Mg}^{2+}\right]$ in solution were expressed in $\mathrm{mmol} / \mathrm{l}$.

$$
\text { Cumulativeleachateofcations }=\sum_{\mathrm{i}=1}^{\mathrm{n}=7} \mathrm{Ci} * \mathrm{Vi}
$$

where $\mathrm{Ci}(\mathrm{mmol} / \mathrm{l})$ and $\mathrm{Vi}(\mathrm{L})$ represent the concentration and volume of cation during the $i$ th leaching event (e.g. when $\mathrm{i}=2$, it means the second leaching event), respectively.

\section{Results and discussion}

\section{Variation of EC and pH in leachate and soil}

The breakthrough curve of EC for each leaching event was presented in Figure1(a). EC in the leachate of each leaching event increased with the addition dosage of leonardite. The peak value of EC occurred at the third leaching event for CK (control) and T1-3, and then the EC gradually decreased during the following leaching processes to reach a relatively stable status. It coincided with previous observations that the mountain-like variation of EC might be caused by the movement of soluble salts to the upper part of the soil column along with the wetting front while the columns were initially saturated from the bottom 

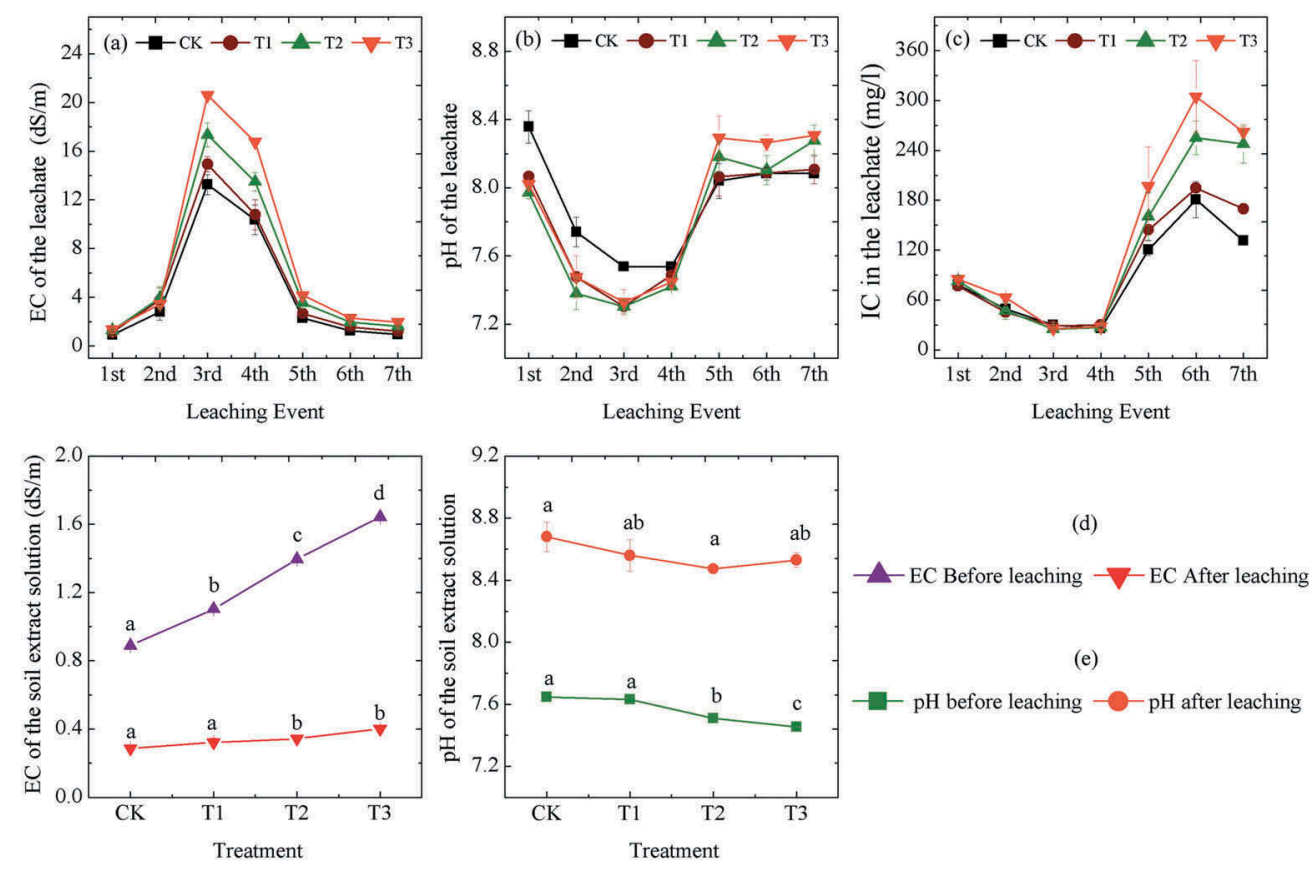

Figure 1. Variation of $\mathrm{EC}, \mathrm{pH}$, and In-organic carbon in leachate of different treatments throughout the leaching process $(\mathrm{a}-\mathrm{c})$ as well as the comparison of $\mathrm{EC}$ or $\mathrm{pH}$ between before and after leaching in soil columns (d-e). (a: the variation of EC in the leachate by different treatments; b: the variation of $\mathrm{pH}$ in the leachate by different treatments; $c$ : the variation of inorganic carbon in the leachate by different treatments; d: comparison of EC in the soil columns by different treatments between before and after leaching; e: comparison of $\mathrm{pH}$ between before and after leaching in the soil columns by different treatments). Note: CK was the control; T1 was the treatment of $10 \mathrm{~g} / \mathrm{kg}$ leonardite dosage; T2 was the treatment of $30 \mathrm{~g} / \mathrm{kg}$ leonardite dosage; T3 was the treatment of $50 \mathrm{~g} / \mathrm{kg}$ leonardite dosage. Different lower case letters indicated significant differences among different treatments at $p<0.05$. The EC and $\mathrm{pH}$ in the soil columns were determined through the extract obtained at soil-water ratio of 1:5.

(Chaganti et al., 2015). A similar phenomenon that EC of leachate increased during the initial leaching was also observed (Jalali \& Ranjbar, 2009). Great changes in EC and pH occurred at the end of leaching experiments. Figure 1(d) shows that the initial EC in the soil solution was correlated to application dosage due to the soluble salt leonardite contained $\left(\mathrm{R}^{2}=0.997\right)$. Final EC of the soil achieved great declination to a level suitable for growing plants after leaching. The EC of CK/T1/T2/T3 was 0.29/0.32/0.34/0.40 dS/m with $67.4 \% / 70.9 \% / 75.7 \% / 75.6 \%$ of salt discharged compared with that before leaching. The decreased EC demonstrated that the reduction of salt and the soil desalination took place. A relatively lower salt content was one of the critical aspects of reclaiming saltaffected soil, which could improve plant growth and microbial activities (Abiala et al., 2018; Jesus et al., 2015).

Soil $\mathrm{pH}$ is an essential indicator to show land arability because it is hard for most of the plants to live in the soil with $\mathrm{pH}>9.0$ or $<2.5$. In addition, the $\mathrm{pH}$ also affects the element speciation of nutrients (Lehmann \& Rillig, 2015). The acid leonardite might potentially benefit to neutralize high $\mathrm{pH}$ of salt-affected soil. Figure 1(b) shows that the leachate $\mathrm{pH}$ initially decreased to reach a minimum value at the third leaching event and then 
increased during the following leaching events. The variation pattern of $\mathrm{pH}$ was just opposite to that of EC in the whole leaching process. The $\mathrm{pH}$ of $\mathrm{CK}$ at the first three leaching events was significantly higher than that of columns with leonardite addition, indicating that leonardite played an important role in adjusting soil $\mathrm{pH}$. The $\mathrm{pH}$ of CK/ T1/T2/T3 reached the lowest of 7.54/7.30/7.30/7.33 at the thirdleaching event. When soil salinity reduced gradually, $\mathrm{pH}$ was found to rise steadily with increased additional dose of leonardite. The similar variation trend of $\mathrm{pH}$ during leaching process was observed in many studies (Cui et al., 2018; Kaschl et al., 2002) and explained as a byproduct brought by leaching or dissolution balance of $\mathrm{CaCO}_{3}$ precipitation $\left(\mathrm{CaCO}_{3}+\mathrm{CO}_{2}+\mathrm{H}_{2} \mathrm{O} \leftrightarrow \mathrm{Ca}^{2+}\right.$ $+2 \mathrm{HCO}_{3}{ }^{-}$) in the soil. $\mathrm{HCO}_{3}{ }^{-} / \mathrm{CO}_{3}{ }^{2-}$ moved more slowly than other anions such as $\mathrm{Cl}^{-}$ or $\mathrm{SO}_{4}{ }^{2-}$. $\mathrm{HCO}_{3}{ }^{-} / \mathrm{CO}_{3}{ }^{2-}$ retained in the soil column and hydrolyzed to produce $\mathrm{OH}^{-}$, which resulted in the increase of soil $\mathrm{pH}$. An interesting phenomenon showed that $\mathrm{pH}$ was corresponding to the inorganic carbon content (Figure 1(c)), indicating that inorganic carbon in the solution resulted in the increase in $\mathrm{pH}$. In addition, variation pattern of $\mathrm{pH}_{\mathrm{CK}}<\mathrm{pH}_{1 \%}<\mathrm{pH}_{3 \%}<\mathrm{pH}_{5 \%}$ might be explained by that the acid leonardite activated $\mathrm{CaCO}_{3}$ of the soil to promote more soluble $\mathrm{Ca}^{2+}$ and $\mathrm{HCO}_{3}{ }^{-}$or $\mathrm{CO}_{3}{ }^{2-}$. This might benefit to the amendment of salt-affected soil since $\mathrm{Ca}^{2+}$ could replace $\mathrm{Na}^{+}$by the process of Soil- $-\mathrm{Na}++\mathrm{Ca}^{2+} \leftrightarrow$ Soil $-\mathrm{Ca}+2 \mathrm{Na}^{+}$.

At the beginning of leaching, the initial $\mathrm{pH}$ of soil column for $\mathrm{CK}$ and T1-3 was around 7.6 (Figure 1(e)). The abundant humic acid contained in leonardite led to a decline of soil $\mathrm{pH}$ with the application dosage. Along with the process of desalination, the $\mathrm{pH}$ increased about 1.0 unit in all treatments. Some researchers once reported that a sodic soil may be produced resulting from leaching saline soils (Rengasamy \& Olsson, 1991), which was similar in this study. However, soil $\mathrm{pH}$ of leonardite treatments was slightly lower than that of CK which demonstrated the ability of neutralization.

\section{Variety of cations $\left(\mathrm{Na}^{+}, \mathrm{Ca}^{2+}, \mathrm{Mg}^{2+}\right.$, and $\left.\mathrm{K}^{+}\right)$in leachate and soil}

The impact of electrolyte effects and cation exchange can be revealed by the leaching process (Reading et al., 2012). $\mathrm{Na}^{+}$was the dominant cation in the water extraction of leonardite to account for $90 \%$ of total digestion cation mass $\left(\mathrm{Na}^{+}, \mathrm{Ca}^{2+}, \mathrm{Mg}^{2+}\right.$, and $\mathrm{K}^{+}$) (Table 2). Content of $\mathrm{Ca}^{2+}, \mathrm{Mg}^{2+}$ or $\mathrm{K}^{+}$in acid digestion of leonardite was almost tenfold higher than that of in water extraction. Leaching was considered to be one of the most efficient method of reducing soil salt. Soluble salt was continuously discharged from columns and $\mathrm{Na}^{+}$was the dominated salt in the leachate (Figure $2(\mathrm{a}-\mathrm{d})$ ). A good relationship existed between the accumulation amount of $\mathrm{Na}^{+}$in the leachate and the addition dose of leonardite $\left(\mathrm{R}^{2}=0.999\right)$. The cumulative mass of $\mathrm{Na}^{+}$that leached out in CK/T1/T2/T3 was 5.40/7.16/10.52/

Table 2. Cations mass of leonardite and soil.

\begin{tabular}{|c|c|c|c|c|}
\hline \multirow[b]{2}{*}{ Item } & $\mathrm{Na}^{+}$ & $\mathrm{K}^{+}$ & $\mathrm{Ca}^{2+}$ & $\mathrm{Mg}^{2+}$ \\
\hline & \multicolumn{4}{|c|}{$\longrightarrow(\mathrm{mg} / \mathrm{g}) \longrightarrow$} \\
\hline Water extraction of leonardite & 7.23 & 0.33 & 0.28 & 0.20 \\
\hline Water extraction of soil & 0.30 & 0.05 & 0.33 & 0.12 \\
\hline Digestion of leonardite by $\mathrm{HNO}_{3}-\mathrm{HClO}_{4}-\mathrm{HF}$ & 11.46 & 2.00 & 7.12 & 1.69 \\
\hline
\end{tabular}

The water extraction of $\mathrm{Na}^{+}, \mathrm{K}^{+}, \mathrm{Ca}^{2+}, \mathrm{Mg}^{2+}$ was determined at the liquid-soil/leonardite ratio of 5:1. The digestion of leonardite was determined according to the $\mathrm{HNO}_{3}-\mathrm{HClO}_{4}-\mathrm{HF}$ method (Bao, 2005). 

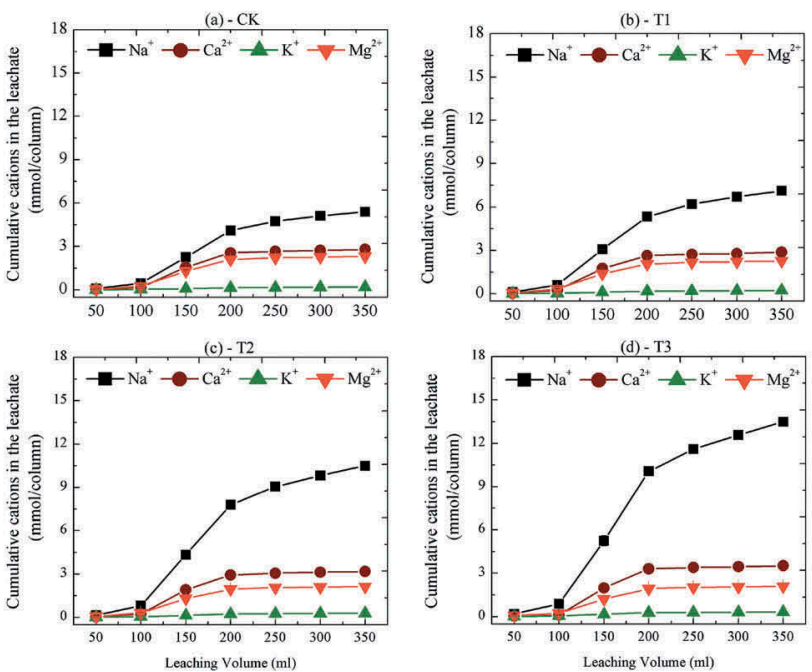

(e) - soil - $\mathrm{Na}^{+}$
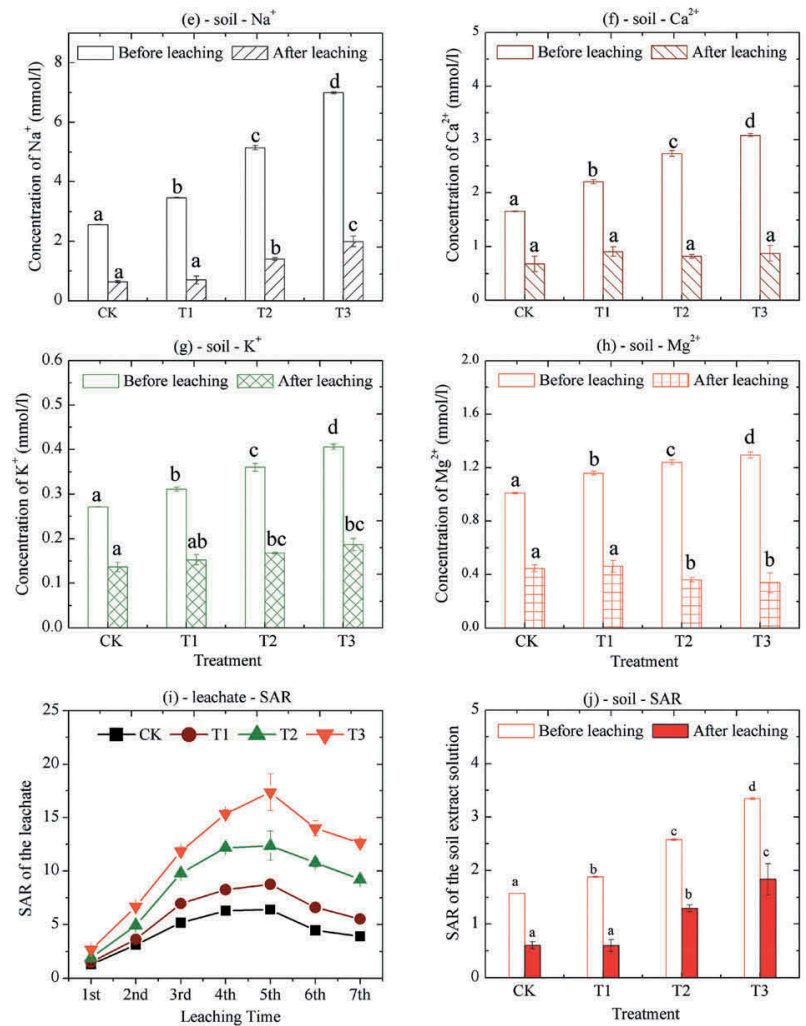

Figure 2. Cumulative cations $\left(\mathrm{Na}^{+}, \mathrm{Ca}^{2+}, \mathrm{K}^{+}, \mathrm{Mg}^{2+}\right)(\mathrm{a}-\mathrm{d})$ and $\mathrm{SAR}$ (i) in the leachate, comparison of $\mathrm{Na}^{+}$, $\mathrm{Ca}^{2+}, \mathrm{K}^{+}, \mathrm{Mg}^{2+}(\mathrm{e}-\mathrm{h})$ and SAR in the soil columns by different treatments (j) (a: cumulative cations of $\mathrm{CK}$ in the leachate; b: cumulative cations of $\mathrm{T} 1$ in the leachate; c: cumulative cations of $\mathrm{T} 2$ in the leachate; $\mathrm{d}$ : cumulative cations of $\mathrm{T} 3$ in the leachate; e: comparison of $\mathrm{Na}^{+}$by different treatments between before and after leaching in soil columns; $\mathrm{f}$ comparison of $\mathrm{Ca}^{2+}$ by different treatments between before and after leaching in soil columns; comparison of $\mathrm{K}^{+}$by different treatments between before and after leaching in soil columns; comparison of $\mathrm{Mg}^{2+}$ by different treatments between before and after leaching in soil columns; i: variation of SAR in the leachate by different treatments; j: comparison of SAR in the soil 
columns by different treatments). Note: $\mathrm{CK}$ was the control; $\mathrm{T} 1$ was the treatment of $10 \mathrm{~g} / \mathrm{kg}$ leonardite dosage; T2 was the treatment of $30 \mathrm{~g} / \mathrm{kg}$ leonardite dosage; $\mathrm{T} 3$ was the treatment of $50 \mathrm{~g} / \mathrm{kg}$ leonardite dosage. Different lower case letters indicated significant differences among different treatments at $p<0.05$. The cations in the soil columns were determined through the extract obtained at soil-water ratio of 1:5.

$13.48 \mathrm{mmol} /$ column at the end of leaching, accounting for 50.33\%/56.97\%/65.13\%/69.31\% of the total cation $\left(\mathrm{Na}^{+}, \mathrm{Ca}^{2+}, \mathrm{Mg}^{2+}\right.$, and $\left.\mathrm{K}^{+}\right)$. The cumulative mass of $\mathrm{Ca}^{2+}$ and $\mathrm{Mg}^{2+}$ increased moderately after $200 \mathrm{ml}$ leaching volume. The final leached-out mass of $\mathrm{Ca}^{2+}$ was $2.81 / 2.87 /$ $3.19 / 3.53 \mathrm{mmol} /$ column while that of $\mathrm{Mg}^{2+}$ was $2.32 / 2.28 / 2.14 / 2.11 \mathrm{mmol} /$ column for CK/ $\mathrm{T} 1 / \mathrm{T} 2 / \mathrm{T} 3$. The loss of $\mathrm{Mg}^{2+}$ decreased with the application dose of leonardite to demonstrate the possible bond with humic substances (Wang et al., 2016). Generally, excessive $\mathrm{Na}^{+}$could lead to soil colloid swelling and structure deterioration to cause low soil nutrients (Ferretti et al., 2018). Therefore, soil salinity damage would be alleviated when more $\mathrm{Na}^{+}$was washed out with the leonardite addition.

Soil salinity is characterized by high amounts of soluble cations like $\mathrm{Na}^{+}, \mathrm{Mg}^{2+}, \mathrm{Ca}^{2+}$. For CK and all applied amendment columns, the content of all cations shown in Figure 2 (e-h) decreased significantly by the end of leaching relative to that of before leaching. At the end of leaching, the content of $\mathrm{Na}^{+}$in $\mathrm{CK}$ and $\mathrm{T} 1-3$ was reduced by $75.1 \%, 79.7 \%$, $72.6 \%$, and $71.5 \%$. It was reported that excessive $\mathrm{Na}^{+}$could cause colloidal dispersion and structural deterioration in salt-affected soils (Fay \& Shi, 2012). Therefore, once soluble and exchangeable $\mathrm{Na}^{+}$were leached out of soil, the damages caused by $\mathrm{Na}^{+}$could be probably alleviated. There was no significant difference among $\mathrm{CK}$ and treatments on the content of $\mathrm{Ca}^{2+}$ in the soil column after leaching $(p<0.05) . \mathrm{K}^{+}$increased with the application dosage, the content of $\mathrm{K}^{+}$in $\mathrm{T} 3$ was nearly three times higher than that of $\mathrm{CK}$, which could provide more nutrients for plants. The amount of $\mathrm{Mg}^{2+}$ in $\mathrm{T} 2$ and $\mathrm{T} 3$ was lower than CK and T1, which was corresponding to the accumulative loss.

SAR, the relative amount of divalent $\mathrm{Ca}^{2+}$ and $\mathrm{Mg}^{2+}$ as well as monovalent $\mathrm{Na}^{+}$ (Bourrie, 2014), reflects the composition of soil solution and the soil exchangeable sodium percentage (ESP). SAR index has been widely identified as a valuable indicator of $\mathrm{Na}^{+}$risk in soils and irrigation. In the process of leaching, SAR reached the highest at the fifth leaching event and then decreased (Figure 2(i)). The SAR value in the leachate increased with the leonardite dosage, demonstrating the role of leonardite in accelerating $\mathrm{Na}^{+}$release. The SAR peak for CK/T1/T2/T3 was 6.39/8.76/12.36/17.36. SAR of soil column for CK/T1/T2/T3 reached $0.61 / 0.60 / 1.29 / 1.84$ at the end, decreasing by $61.1 \% /$ $68.1 \% / 50.0 \% / 44.9 \%$ compared with the initial (Figure 2(j)). The declined $\mathrm{Na}^{+}$content contributed to the most of reduced final SAR (Figure 2(e)).

\section{Variation of organic matters in the leachate and soil}

Leonardite is rich in organic materials like humic substances. DOM such as humic substances might be released with salts or be resorted in soil solution during leaching to improve the plant growth (García et al., 2016; Olaetxea et al., 2018). TOC was used as an indicator representing DOM in this study. Contents of TOC content decreased firstly, increased from the second leaching event until the fifth event, and finally decreased again (Figure 3(a)). Higher TOC content occurred with a larger leonardite application dosage. 
(a) - leachate - TOC

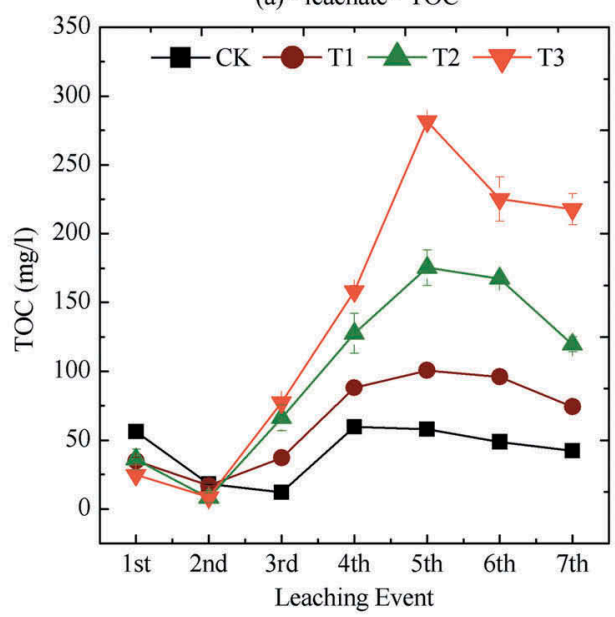

(c) - leachate $-\mathrm{E}_{2} / \mathrm{E}_{3}$

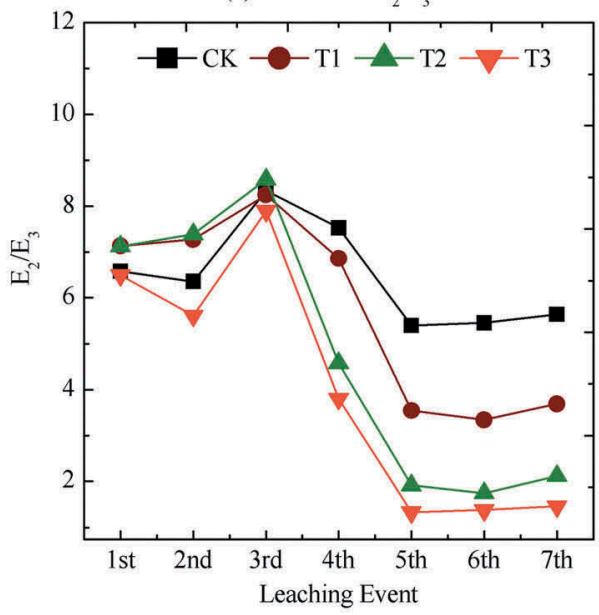

(b) - soil - SOM

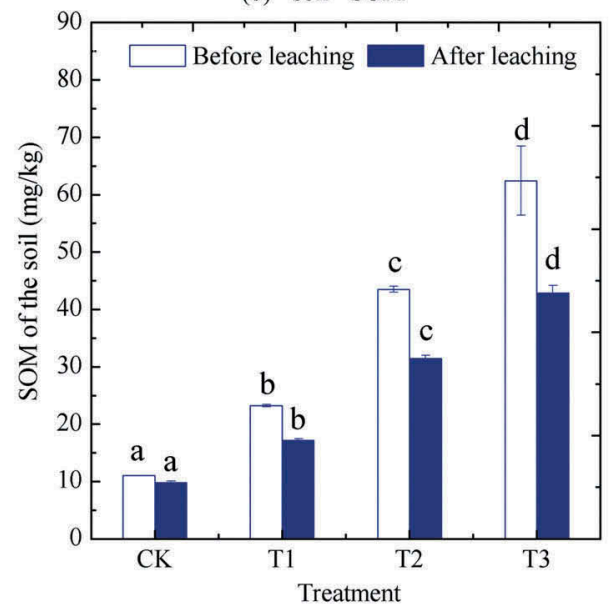

(d) - leachate $-\mathrm{E}_{4} / \mathrm{E}_{6}$

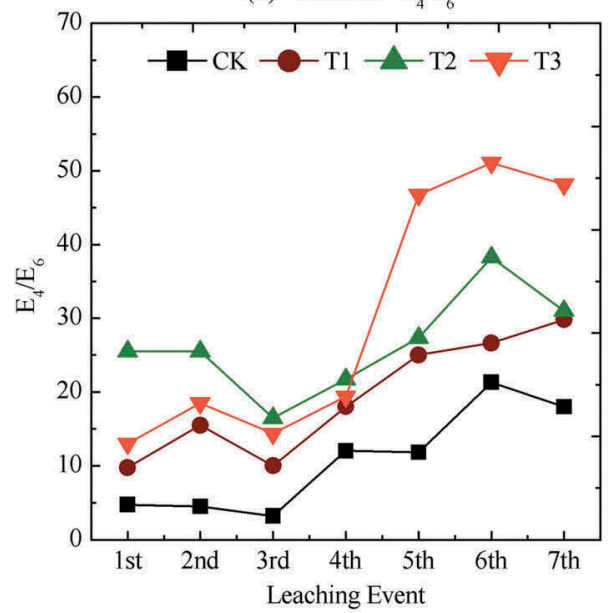

Figure 3. Variation of $E_{2} / E_{3}, E_{4} / E_{6}$ and TOC content in the leachate, comparison of SOM between before and after leaching in the soil columns. (a: variation of TOC content in the leachate by different treatments; b: comparison of SOM between before and after leaching in the soil columns; c: variation of $E_{2} / E_{3}$ in the leachate by different treatments; $d$ : variation of $E_{4} / E_{6}$ in the leachate by different treatments). Note: CK was the control; T1 was the treatment of $10 \mathrm{~g} / \mathrm{kg}$ leonardite dosage; T2 was the treatment of $30 \mathrm{~g} / \mathrm{kg}$ leonardite dosage; T3 was the treatment of $50 \mathrm{~g} / \mathrm{kg}$ leonardite dosage. Different lower case letters indicated significant differences among different treatments at $p<0.05$.

The highest content of TOC in CK/T1/T2/T3 reached 59.78/100.65/175.39/281.58 mg/l with $\mathrm{pH}$ rapidly increasing (Figure $1(\mathrm{~b})$ ), indicating the possible relationship between $\mathrm{pH}$ and TOC loss.

SOM, a critical component of soil and an important parameter for sustaining soil productivity plays an essential role in a series of ecological and environmental processes including plant growth, the sorption, and distribution of plant nutrients (Petrov et al., 2017; Senesi \& Loffredo, 2018). The reclamation of salt-affected soil by leonardite in this study promoted the content of SOM significantly (Figure 3(b)). SOM in T1/T2/T3 increased by 
$110.9 \% / 295.2 \% / 466.9 \%$ compared with that of CK. The final content of SOM after leaching in CK/T1/T2/T3 was $9.74 / 17.20 / 31.41 / 42.88 \mathrm{~g} / \mathrm{kg}$ and lower than that before leaching with SOM content of 11.01/23.22/43.51/62.42 for CK/T1/T2/T3. The result indicated the losses of soluble organic matter to some extent during the leaching process.

UV-Vis spectroscopy was utilized as a simple and informative method in order to describe the molecular properties of the organic materials (Shirshova et al., 2006). The $\mathrm{E}_{2} / \mathrm{E}_{3}$ absorbance ratio measured at $250 / 365 \mathrm{~nm}$ was inverse to the molecular size and aromaticity (Peuravuori \& Pihlaja, 1997). The value of $\mathrm{E}_{2} / \mathrm{E}_{3}$ in leachate fluctuated at the beginning of leaching with 6.59/7.13/7.12/6.50 for CK/T1/T2/T3, then decreased from the third to the fifth leaching event, and finally kept stable or slightly rose at the end of the leaching (Figure 3(c)). The final $\mathrm{E}_{2} / \mathrm{E}_{3}$ ratio of leachate for $\mathrm{CK} / \mathrm{T} 1 / \mathrm{T} 2 / \mathrm{T} 3$ was $5.64 / 3.69 / 2.12 / 1.46$, indicating that the lower $\mathrm{E}_{2} / \mathrm{E}_{3}$ ratio was accompanied by higher leonardite dosage. The variation trend of $\mathrm{E}_{2} / \mathrm{E}_{3}$ implied that dissolved organic matter with small molecular weight was firstly washed down and molecular weight in the leachate became larger due to variation of the salt and $\mathrm{pH}$ of soil during the leaching proceeding (Figure 1(b)). After the third leaching event, $\mathrm{pH}$ rapidly increased to promote the release of humic acids (HAs) contained in leonardite (Klučáková \& Kolajová, 2014). The dissolved HAs had the capacity of exchanging or complexing with cations such as $\mathrm{Na}^{+}$or $\mathrm{Ca}^{2+}$, reducing the strength of ions, thereby alleviating the damage to salt (Cheng et al., 2016; Maghsoodloo et al., 2011; Olaetxea et al., 2018).

It is reported that the $\mathrm{E}_{4} / \mathrm{E}_{6}$ absorbance ratio determined at $465 \mathrm{~nm}$ and $665 \mathrm{~nm}$ is proportional to the degree of humification (Zalba et al., 2016) and to the molecular weight of humic substances. High $\mathrm{E}_{4} / \mathrm{E}_{6}$ absorbance ratio reflected the relative high aromaticity degree and large molecular mass (Chen et al., 1977; Deng et al., 2019; Li \& Hur, 2017). The ratio of $\mathrm{E}_{4} / \mathrm{E}_{6}$ generally increased with the leonardite dosage, contrary to that of $\mathrm{E}_{2} / \mathrm{E}_{3}$ (Figure $3(\mathrm{~d})$ ). The final value of $\mathrm{E}_{4} / \mathrm{E}_{6}$ in leachate was $18.00 / 29.81 / 31.01 / 48.14$ for CK/T1/ T2/T3 and higher than the initial value, indicating that the aromaticity degree increased with the application dosage of leonardite and number of leaching events.

Fulvic acids are lower in molecular mass and more complex than humic acids of the same origin (Vieyra et al., 2009). Fulvic acids could disperse in solution at any $\mathrm{pH}$ (Canellas et al., 2015). Moreover, the solubility of humic substances had a close relationship with $\mathrm{pH}$. Fulvic acids were probably discharged at the initial stage of leaching, and humic acids were released with the rising $\mathrm{pH}$ as the undergoing leaching process. Therefore, controlling the $\mathrm{pH}$ in the process of leaching could benefit for reducing loss of organic matters.

After leaching, the air-dried soil was examined by FTIR in the spectral range of $400-$ $4000 \mathrm{~cm}^{-1}$ of the wavenumber. The spectral signals of CK/T1/T2/T3 were similar in shape according to the FTIR analysis (Figure 4). The fingerprint peaks for SOM were limited due to the relatively low concentration and technical challenge for analyzing whole soil particles with FTIR (Calderon et al., 2011; Simonetti et al., 2012). Generally speaking, wavenumbers in the range of $500-1200 \mathrm{~cm}^{-1}$ indicate the specific absorptions of soil minerals such as clay, quartz, or iron oxides (Xing et al., 2016; Zhao et al., 2016). The spectra in the range of $1600-1750 \mathrm{~cm}^{-1}$ normally contain fingerprint peaks for functional groups of amides, carboxylates, and aromatics (Wang et al., 2017; Xing et al., 2016). A small peak at $1650 \mathrm{~cm}^{-1}$ was detected for soils in this study. The small peaks near 2894 and $2985 \mathrm{~cm}^{-1}$ were assigned to characteristic for the presence of aliphatic carbon and the peaks became significant as the leonardite dosage increased, which corresponded to the result of $\mathrm{E}_{4} / \mathrm{E}_{6}$. 


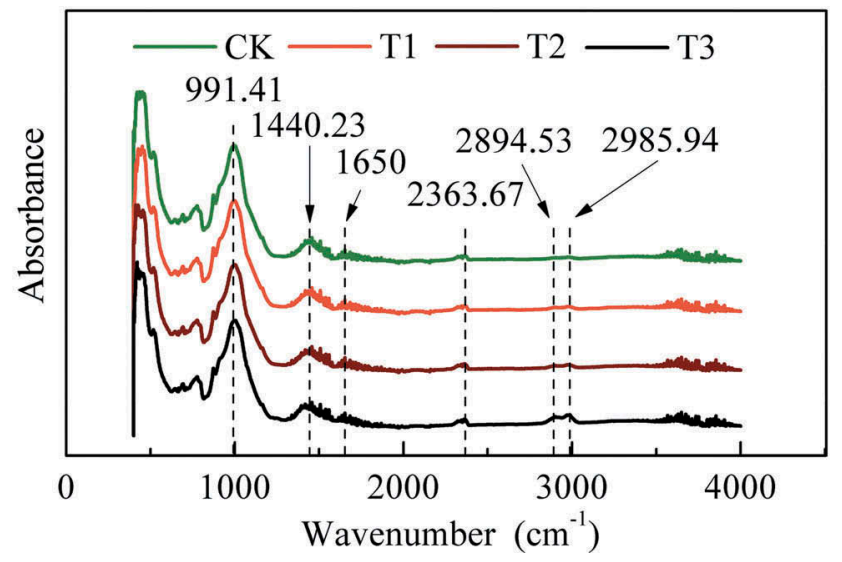

Figure 4. FTIR analysis of soils after leaching in CK and T1-3 columns. Note: CK was the control; T1 was the treatment of $10 \mathrm{~g} / \mathrm{kg}$ leonardite dosage; T2 was the treatment of $30 \mathrm{~g} / \mathrm{kg}$ leonardite dosage; T3 was the treatment of $50 \mathrm{~g} / \mathrm{kg}$ leonardite dosage.

\section{Conclusions}

The amelioration of salt-affected soil in the Yellow River Delta could not only promote the yield but also increase the income of farmers. This study showed a positive effect on amending the salt-affected soil by leonardite to provide some guidance in the field application. The results demonstrated that the simulated rainfall process of leaching could effectively reduce salts in the soil. Cation composition changed during the leaching process and $\mathrm{Na}^{+}$content that caused the most of the damage could be reduced to a low degree. The SAR of the soil thereby declined consequently. The content of SOM was promoted significantly as leonardite once applied. The leonardite dosage of $1 \%$ in the field application was recommended by considering the lower cost and relatively better effect on salt leaching. In addition, the increase of soil $\mathrm{pH}$ caused by desalination should be paid more attention since humic substances that were sensitive to $\mathrm{pH}$. Therefore, the adjustment of $\mathrm{pH}$ would be useful to prevent the organic matters from leaching.

\section{Acknowledgments}

The authors would like to thank the reviewers for their valuable suggestions and comments on the manuscript.

\section{Disclosure statement}

No potential conflict of interest was reported by the authors.

\section{Funding}

This work was supported by the Chinese National Key Research and Development Program [2016YFD0200303]; National Natural Science Foundation of China [41671319]; Taishan Scholars Program of Shandong Province [No. tsqn201812116]; One Hundred Talents Program 
of Chinese Academy of Sciences [Y629041021]; Two-Hundred Talents Plan of Yantai [Y739011021], and Youth Innovation Team Project for Talent Introduction and Cultivation in Universities of Shandong Province.

\section{References}

Abiala, M. A., Abdelrahman, M., Burritt, D. J., \& Tran, L. S. P. (2018). Salt stress tolerance mechanisms and potential applications of legumes for sustainable reclamation of salt-degraded soils. Land Degradation \& Development, 29(10), 3812-3822. https://doi.org/10.1002/ldr.3095

Ahmed, M. B., Zhou, J. L., Ngo, H. H., \& Guo, W. (2016). Insight into biochar properties and its cost analysis. Biomass and Bioenergy, 84, 76-86. https://doi.org/10.1016/j.biombioe.2015.11.002

Bao, S. D. (2005). Soil agricultural chemistry analysis (3rd ed.). China Agriculture Press.

Barone, V., Bertoldo, G., Magro, F., Broccanello, C., Puglisi, I., Baglieri, A., Cagnin, M., Concheri, G., Squartini, A., Nardi, S., \& Stevanato, P. (2019). Molecular and morphological changes induced by leonardite-based biostimulant in beta vulgaris L. Plants, 8(6), 181. https://doi.org/ $10.3390 /$ plants8060181

Bourrie, G. (2014). Swelling clays and salt-affected soils: Demixing of $\mathrm{Na} / \mathrm{Ca}$ clays as the rationale for discouraging the use of sodium adsorption ratio (SAR). Eurasian Journal of Soil Science, 3(4), 245253. http://doi.org/10.18393/ejss.12357

Calderon, F. J., Reeves III, J. B., Collins, H. P., \& Paul, E. A. (2011). Chemical differences in soil organic matter fractions determined by diffuse-reflectance mid-infrared spectroscopy. Soil Science Society of America Journal, 75(2), 568-579. https://doi.org/10.2136/sssaj2009.0375

Canellas, L. P., Olivares, F. L., Aguiar, N. O., Jones, D. L., Nebbioso, A., Mazzei, P., \& Piccolo, A. (2015). Humic and fulvic acids as biostimulants in horticulture. Scientia Horticulturae, 196, 15 27. https://doi.org/10.1016/j.scienta.2015.09.013

Chaganti, V. N., Crohn, D. M., \& Šimůnek, J. (2015). Leaching and reclamation of a biochar and compost amended saline-sodic soil with moderate SAR reclaimed water. Agricultural Water Management, 158, 255-265. https://doi.org/10.1016/j.agwat.2015.05.016

Chen, Y., Senesi, N., \& Schnitzer, M. (1977). Information provided on humic substances by E4/E6 ratios. Soil Science Society of America Journal, 41(2), 352-358. https://doi.org/10.2136/sssaj1977. $03615995004100020037 \mathrm{x}$

Cheng, D., Liao, P., \& Yuan, S. (2016). Effects of ionic strength and cationic type on humic acid facilitated transport of tetracycline in porous media. Chemical Engineering Journal, 284, 389394. https://doi.org/10.1016/j.cej.2015.08.159

Cui, S., Zhang, J., Sun, M., Chen, H., \& Feng, Z. (2018). Leaching effectiveness of desalinization by rainfall combined with wheat straw mulching on heavy saline soil. Archives of Agronomy and Soil Science, 64(7), 891-902. https://doi.org/10.1080/03650340.2017.1407871

Deng, Y., Chen, N., Feng, C., Chen, F., Wang, H., Feng, Z., Zheng, Y., Kuang, P., \& Hu, W. (2019). Research on complexation ability, aromaticity, mobility and cytotoxicity of humic-like substances during degradation process by electrochemical oxidation. Environmental Pollution, 251, 811-820. https://doi.org/10.1016/j.envpol.2019.05.047

Diacono, M., \& Montemurro, F. (2015). Effectiveness of organic wastes as fertilizers and amendments in salt-affected soils. Agriculture, 5(2), 221-230. https://doi.org/10.3390/agriculture5020221

Dobrzanski, A., \& Anyszka, Z. (2008). Response of carrots to application of natural extracts from seaweed (sargassum sp.) - algaminoplant and from leonardite - humiplant. Journal of Research \& Applications in Agricultural Engineering, 53(3), 53-58. http://doi.org/10.1016/S0022-3468 (85)80182-2

Fay, L., \& Shi, X. (2012). Environmental impacts of chemicals for snow and ice control: State of the knowledge. Water Air and Soil Pollution, 223(5), 2751-2770. https://doi.org/10.1007/s11270011-1064-6

Ferretti, G., Di Giuseppe, D., Faccini, B., \& Coltorti, M. (2018). Mitigation of sodium risk in a sandy agricultural soil by the use of natural zeolites. Environmental Monitoring and Assessment, 190(11), 646. https://doi.org/10.1007/s10661-018-7027-2 
Gao, T. G., Jiang, F., Yang, J. S., Li, B. Z., \& Yuan, H. L. (2012). Biodegradation of leonardite by an alkali-producing bacterial community and characterization of the degraded products. Applied Microbiology and Biotechnology, 93(6), 2581-2590. https://doi.org/10.1007/s00253-011-3669-5

García, A. C., Santos, L. A., Ambrósio de Souza, L. G., Tavares, O. C. H., Zonta, E., Gomes, E. T. M., García-Mina, J. M., \& Berbara, R. L. L. (2016). Vermicompost humic acids modulate the accumulation and metabolism of ROS in rice plants. Journal of Plant Physiology, 192, 56-63. https://doi.org/10.1016/j.jplph.2016.01.008

Ghafoor, A., Murtaza, G., Rehman, M. Z., \& Sabir, M. (2012). Reclamation and salt leaching efficiency for tile drained saline-sodic soil using marginal quality water for irrigating rice and wheat crops. Land Degradation \& Development, 23(1), 1-9. https://doi.org/10.1002/ldr.1033

Huang, Q., Li, M., Chen, Z., \& Li, F. (2011). Land consolidation: An approach for sustainable development in rural China. Ambio, 40(1), 93-95. https://doi.org/10.1007/s13280-010-0087-3

Jalali, M., \& Ranjbar, F. (2009). Effects of sodic water on soil sodicity and nutrient leaching in poultry and sheep manure amended soils. Geoderma, 153(1-2), 194-204. https://doi.org/10. 1016/j.geoderma.2009.08.004

Jesus, J. M., Danko, A. S., Fiúza, A., \& Borges, M. T. (2015). Phytoremediation of salt-affected soils: A review of processes, applicability, and the impact of climate change. Environmental Science and Pollution Research, 22(9), 6511-6525. https://doi.org/10.1007/s11356-015-4205-4

Kaschl, A., Römheld, V., \& Chen, Y. (2002). The influence of soluble organic matter from municipal solid waste compost on trace metal leaching in calcareous soils. Science of the Total Environment, 291(1-3), 45-57. https://doi.org/10.1016/S0048-9697(01)01091-9

Klučáková, M., \& Kolajová, R. (2014). Dissociation ability of humic acids: Spectroscopic determination of $\mathrm{pKa}$ and comparison with multi-step mechanism. Reactive and Functional Polymers, 78, 1-6. https://doi.org/10.1016/j.reactfunctpolym.2014.02.005

Lakhdar, A., Rabhi, M., Ghnaya, T., Montemurro, F., Jedidi, N., \& Abdelly, C. (2009). Effectiveness of compost use in salt-affected soil. Journal of Hazardous Materials, 171(1-3), 29-37. https:// doi.org/10.1016/j.jhazmat.2009.05.132

Lehmann, A., \& Rillig, M. C. (2015). Arbuscular mycorrhizal contribution to copper, manganese and iron nutrient concentrations in crops-A meta-analysis. Soil Biology and Biochemistry, 81, 147-158. https://doi.org/10.1016/j.soilbio.2014.11.013

Li, P., \& Hur, J. (2017). Utilization of UV-Vis spectroscopy and related data analyses for dissolved organic matter (DOM) studies: A review. Critical Reviews in Environmental Science and Technology, 47(3), 131-154. https://doi.org/10.1080/10643389.2017.1309186

Liu, L., Long, X., Shao, H., Liu, Z., Tao, Y., Zhou, Q., \& Zong, J. (2015). Ameliorants improve saline-alkaline soils on a large scale in northern jiangsu province, China. Ecological Engineering, 81, 328-334. https://doi.org/10.1016/j.ecoleng.2015.04.032

Maghsoodloo, S., Noroozi, B., Haghi, A. K., \& Sorial, G. A. (2011). Consequence of chitosan treating on the adsorption of humic acid by granular activated carbon. Journal of Hazardous Materials, 191(1-3), 380-387. https://doi.org/10.1016/j.jhazmat.2011.04.096

Mao, W., Kang, S., Wan, Y., Sun, Y., Li, X., \& Wang, Y. (2016). Yellow river sediment as a soil amendment for amelioration of saline land in the yellow river delta. Land Degradation \& Development, 27(6), 1595-1602. https://doi.org/10.1002/ldr.2323

Mau, Y., \& Porporato, A. (2016). Optimal control solutions to sodic soil reclamation. Advances in Water Resources, 91, 37-45. https://doi.org/10.1016/j.advwatres.2016.02.014

Miller, J., Beasley, B., Drury, C., Larney, F., \& Hao, X. (2017). Surface soil salinity and soluble salts after 15 applications of composted or stockpiled manure with straw or woodchips. Compost Science \& Utilization, 25(1), 36-47. https://doi.org/10.1080/1065657X.2016.1176968

Olaetxea, M., De Hita, D., Garcia, C. A., Fuentes, M., Baigorri, R., Mora, V., \& Berbara, R. L. (2018). Hypothetical framework integrating the main mechanisms involved in the promoting action of rhizospheric humic substances on plant root-and shoot-growth. Applied Soil Ecology, 123, 521-537. https://doi.org/10.1016/j.apsoil.2017.06.007

Petrov, D., Tunega, D., Gerzabek, M. H., \& Oostenbrink, C. (2017). Molecular dynamics simulations of the standard leonardite humic acid: Microscopic analysis of the structure and dynamics. Environmental Science \& Technology, 51(10), 5414-5424. https://doi.org/10.1021/acs.est.7b00266 
Peuravuori, J., \& Pihlaja, K. (1997). Molecular size distribution and spectroscopic properties of aquatic humic substances. Analytica chimica acta, 337(2), 133-149. https://doi.org/10.1016/ S0003-2670(96)00412-6

Raychev, T., Popandova, S., Józefaciuk, G., Hajnos, M., \& Sokolowska, Z. (2001). Physicochemical reclamation of saline soils using coal powder. International Agrophysics, 15(1), 51-54.

Reading, L. P., Baumgartl, T., Bristow, K. L., \& Lockington, D. A. (2012). Hydraulic conductivity increases in a sodic clay soil in response to gypsum applications: Impacts of bulk density and cation exchange. Soil Science, 177(3), 165-171. https://doi.org/10.1097/SS.0b013e3182408f4f

Rengasamy, P., \& Olsson, K. A. (1991). Sodicity and soil structure. Australian Journal of Soil Research, 29(6), 935-952. https://doi.org/10.1071/SR9910935

Saifullah, Dahlawi, S., Naeem, A., Rengel, Z., \& Naidu, R. (2018). Biochar application for the remediation of salt-affected soils: Challenges and opportunities. Science of the Total Environment, 625, 320-335. https://doi.org/10.1016/j.scitotenv.2017.12.257

Senesi, N., \& Loffredo, E. (2018). The chemistry of soil organic matter. In Soil physical chemistry (Sparks, D.L. ed), pp. 239-370.

Shaygan, M., Baumgartl, T., Arnold, S., \& Reading, L. P. (2018). The effect of soil physical amendments on reclamation of a saline-sodic soil: Simulation of salt leaching using HYDRUS-1D. Soil Research, 56(8), 829-845. https://doi.org/10.1071/SR18047

Shirshova, L. T., Ghabbour, E. A., \& Davies, G. (2006). Spectroscopic characterization of humic acid fractions isolated from soil using different extraction procedures. Geoderma, 133(3-4), 204-216. https://doi.org/10.1016/j.geoderma.2005.07.007

Simonetti, G., Francioso, O., Nardi, S., Berti, A., Brugnoli, E., Lugato, E., \& Morari, F. (2012). Characterization of humic carbon in soil aggregates in a long-term experiment with manure and mineral fertilization. Soil Science Society of America Journal, 76(3), 880-890. https://doi.org/10.2136/ sssaj2011.0243

Srivastava, P. K., Gupta, M. S., Singh, N., \& Tewari, S. K. (2016). Amelioration of sodic soil for wheat cultivation using bioaugmented organic soil amendment. Land Degradation \& Development, 27(4), 1245-1254. https://doi.org/10.1002/ldr.2292

Vieyra, F. E. M., Palazzi, V. I., de Pinto, M. I. S., \& Borsarelli, C. D. (2009). Combined UV-Vis absorbance and fluorescence properties of extracted humic substances-like for characterization of composting evolution of domestic solid wastes. Geoderma, 151(3-4), 61-67. https://doi.org/ 10.1016/j.geoderma.2009.03.006

Wang, W., Feng, P., Yang, Q., Wang, W., \& Wang, X. (2016). Effects of sodium, magnesium, and calcium salts on the coagulation performance of cucurbit uril for humic acid removal from synthetic seawater. Desalination, 386, 77-83. https://doi.org/10.1016/j.desal.2016.02.038

Wang, Y., Zhang, X., Zhang, X., Meng, Q., Gao, F., \& Zhang, Y. (2017). Characterization of spectral responses of dissolved organic matter (DOM) for atrazine binding during the sorption process onto black soil. Chemosphere, 180, 531-539. https://doi.org/10.1016/j.chemosphere.2017.04.063

Xing, Z., Du, C., Tian, K., Ma, F., Shen, Y., \& Zhou, J. (2016). Application of FTIR-PAS and Raman spectroscopies for the determination of organic matter in farmland soils. Talanta, 158, 262-269. https://doi.org/10.1016/j.talanta.2016.05.076

Zalba, P., Amiotti, N. M., Galantini, J. A., \& Pistola, S. (2016). Soil humic and fulvic acids from different land-use systems evaluated by E4/E6 ratios. Communications in Soil Science and Plant Analysis, 47(13-14), 1675-1679. https://doi.org/10.1080/00103624.2016.1206558

Zhao, Q., Poulson, S. R., Obrist, D., Sumaila, S., Dynes, J. J., McBeth, J. M., \& Yang, Y. (2016). Ironbound organic carbon in forest soils: Quantification and characterization. Biogeosciences, 13 (16), 4777-4788. https://doi.org/10.5194/bg-13-4777-2016 